\title{
Research on the Measurement of green Development level of Agriculture and Animal Husbandry in Haixi Prefecture
}

\author{
WenYu ${ }^{1}$, Dingshengxi ${ }^{2, a}$ \\ ${ }^{1}$ School of Finance and Economics, Qinghai University \\ ${ }^{2}$ School of Finance and Economics, Qinghai University
}

\begin{abstract}
In this paper, the evaluation index system of the green development level of agriculture and animal husbandry in Haixi city was established, and the entropy weight grey correlation TOPSIS model was used to calculate the green development level of agriculture and animal husbandry in Haixi city from 2001 to 2019. The countermeasures and suggestions to promote the green development of agriculture and animal husbandry in Haixi prefecture were put forward.
\end{abstract}

\section{Introduction}

The green development of agriculture and animal husbandry is aimed at the sustainable development of economy, society and ecological environment. It is urgent to adjust and optimize the structure of agriculture and animal husbandry industry, improve the output efficiency of agriculture and animal husbandry, and realize the stable income increase of farmers and herdsmen ${ }^{[1]}$.The agriculture and animal husbandry of Haixi autonomous prefecture gave full play to its unique advantages in geography and climate, and vigorously promoted the adjustment of industrial structure and optimized industrial layout.In this context, this paper makes a dynamic measurement and evaluation of the green development level of agriculture and animal husbandry in Haixi prefecture from the aspects of economy, society and ecological environment.

\section{Development status of agriculture and animal husbandry in Haixi Prefecture}

In 2019, the agriculture and animal husbandry economy of Haixi state made steady progress. According to the statistics of Haixi, the added value of agriculture and animal husbandry reached 3.616 billion yuan, up $2.1 \%$.Grain output reached 78,000 tons, an increase of 2.9 percent over the previous year.The total cultivated land area is $894,600 \mathrm{mu}$. There are $3.172,500$ herbivorous animals in the whole state, and the total output of meat is 35,679 tons.Infrastructure construction in rural areas of the prefecture was strengthened.The total power of agricultural machinery is $425,400 \mathrm{kw}$.There were 525 hospitals and health centers, 3,771 health workers and 3,307 beds.In general, the rural construction of Shanghai $\mathrm{Xi}$ prefecture has been improving, and the infrastructure construction has been increasingly strengthened.The living standards of farmers and herdsmen are also improving. The per capita disposable income of rural residents is 15,052 yuan, up $8.4 \%$.At the end of the year, 3,944 farmers and herdsmen from 1,576 households enjoyed the minimum living allowance, and a total of 18.0589 million yuan was paid.In terms of ecological environment, the forest coverage rate of Haixi city was $3.5 \%$, and the use of pesticide was 19.20 tons, $6.9 \%$ less than that of the previous year.

\section{3 measurement and evaluation of the green development level of agriculture and Animal husbandry in Haixi Prefecture}

\subsection{Construction of evaluation index system of green development level of Agriculture and Animal husbandry in Haixi Prefecture}

For accurate assessment of 2001-2019, the dynamic changes of the farming and animal husbandry green development level, when setting the specific evaluation indicators, fully considering the index selection of systemic, scientific and the principle of data availability and draw lessons from the academic circles of the existing research results [3] - [5], and constructs the evaluation index system of farming and animal husbandry, village green development level (table 1).

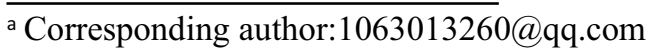


Table 1. Evaluation index system of green development level of Agriculture and Animal husbandry in Haixi Prefecture

\begin{tabular}{|c|c|c|c|c|}
\hline $\begin{array}{l}\text { The } \\
\text { layer }\end{array}$ & Level indicators & $\begin{array}{l}\text { The secondary } \\
\text { indicators }\end{array}$ & Level 3 indicators & $\begin{array}{l}\text { Index } \\
\text { attribute }\end{array}$ \\
\hline \multirow{17}{*}{$\begin{array}{l}\text { Level of green } \\
\text { development } \\
\text { of agriculture } \\
\text { and animal } \\
\text { husbandry }\end{array}$} & \multirow{7}{*}{$\begin{array}{l}\text { Agricultural and } \\
\text { animal } \\
\text { husbandry } \\
\text { economy }\end{array}$} & \multirow{3}{*}{$\begin{array}{l}\text { Economies of } \\
\text { scale }\end{array}$} & Grain output per capita X1 & positive \\
\hline & & & Total crop sown area X2 & positive \\
\hline & & & Agricultural and animal husbandry practitioners X3 & positive \\
\hline & & \multirow{4}{*}{$\begin{array}{l}\text { Economic } \\
\text { efficiency }\end{array}$} & Gross output value of agriculture and animal husbandry X4 & positive \\
\hline & & & Agricultural and animal husbandry labor productivity X5 & positive \\
\hline & & & Agricultural mechanization degree X6 & positive \\
\hline & & & Rate per unit animal husbandry product $\mathrm{X} 7$ & positive \\
\hline & \multirow{5}{*}{$\begin{array}{l}\text { Rural social } \\
\text { development }\end{array}$} & \multirow{2}{*}{$\begin{array}{l}\text { The standard of } \\
\text { living }\end{array}$} & The engel's coefficient for rural residents $\mathrm{X} 8$ & negative \\
\hline & & & Net income per capita for rural residents X9 & positive \\
\hline & & \multirow{3}{*}{ infrastructure } & Rural electricity consumption $\mathrm{X} 10$ & positive \\
\hline & & & Number of owned medical institutions X11 & positive \\
\hline & & & The number of mobile phones per 100 households is $\mathrm{X} 12$ & positive \\
\hline & \multirow{5}{*}{$\begin{array}{l}\text { Agricultural and } \\
\text { animal } \\
\text { husbandry } \\
\text { ecological } \\
\text { environment }\end{array}$} & \multirow{3}{*}{$\begin{array}{l}\text { The } \\
\text { environmental } \\
\text { pollution }\end{array}$} & Fertilizer intensity X13 & negative \\
\hline & & & agricultural plastic film application intensity X14 & negative \\
\hline & & & Intensity of pesticide application X15 & negative \\
\hline & & \multirow{2}{*}{$\begin{array}{l}\text { Ecological } \\
\text { management }\end{array}$} & Forest coverage rate $\mathrm{X} 16$ & positive \\
\hline & & & Afforestation area $\mathrm{x} 17$ & positive \\
\hline
\end{tabular}

(5) Calculate the information utility value of the

\subsection{TOPSIS method of entropy weight grey correlation}

(1) Collection and collation of original data

Assuming that there are $\mathrm{M}$ evaluation units and $\mathrm{N}$ evaluation indexes in the agricultural green development evaluation system, let the evaluation matrix be:

$\mathrm{X}=\left(\mathrm{x}_{\mathrm{ij}}\right)_{\mathrm{m} \times \mathrm{n}^{\prime}},(0 \ll \mathrm{i} \ll \mathrm{m}, 0 \ll \mathrm{j} \ll \mathrm{n})$

$\mathrm{Xij}$ represents the value of the JTH evaluation index in the I evaluation unit.

(2) Dimensionless treatment of indicators

The extreme value method is adopted in the dimensionless treatment of indicators, and the treatment methods for forward type indicators and reverse type indicators are shown in Equation (2) respectively.

$\mathrm{x}_{\mathrm{ij}}^{\prime}=\frac{\mathrm{x}_{\mathrm{ij}}-\mathrm{x}_{\min }}{\mathrm{x}_{\max }-\mathrm{x}_{\min }}, \mathrm{x}_{\mathrm{ij}}^{\prime}=\frac{\mathrm{x}_{\max }-\mathrm{x}_{\mathrm{ij}}}{\mathrm{x}_{\max }-\mathrm{x}_{\min }}$

Where $\mathrm{xj}$ is the JTH index value, Xmax is the maximum value of the JTH index, and Xmin is the minimum value of the JTH index, and is its standardized value.In order to eliminate the influence of standardized index value on logarithmic calculation, coordinate translation should be carried out. The formula is as follows:

$\mathrm{y}_{\mathrm{ij}}=\mathrm{x}_{\mathrm{ij}}^{\prime}+\mathrm{A}$, In this paper, $\mathrm{A}$ is 0.0001

(3) Calculate the proportion of the index value in the year I of the JTH index $\mathrm{p}_{\mathrm{ij}}$

$\mathrm{p}_{\mathrm{ij}}=\frac{\mathrm{y}_{\mathrm{ij}}}{\sum_{\mathrm{i}=1}^{\mathrm{m}} \mathrm{y}_{\mathrm{ij}}},\left(0 \ll \mathrm{p}_{\mathrm{ij}} \ll 1\right)$

(4) Calculate the information entropy of the JTH index $e_{j}$ :

$\mathrm{e}_{\mathrm{j}}=-\mathrm{K} \sum_{\mathrm{i}=1}^{\mathrm{m}} \mathrm{p}_{\mathrm{ij}} \ln _{\mathrm{ij}},\left(K\right.$ is constant $\left., \mathrm{K}=\frac{1}{\ln \mathrm{m}}, \mathrm{m}=11\right)$
JTH index $d_{j}$ :

$\mathrm{d}_{\mathrm{j}}=1-\mathrm{e}_{\mathrm{j}}$

(c) Calculate the weight of evaluation index

$w_{j}=\frac{d_{j}}{\sum_{i=1}^{m} d_{j}}$

$\mathrm{w}_{\mathrm{j}}^{\prime}=\frac{\mathrm{w}_{\mathrm{j}}}{\sum_{\mathrm{i}=1}^{\mathrm{e}} \mathrm{w}_{\mathrm{j}}}$

Where, is the total ranking weight of the JTH index, is the single ranking weight of the JTH index in each subsystem (criterion layer), and $\mathrm{E}$ is the number of evaluation indexes in each criterion layer.

(7) Calculate the weighted normalized matrix:

$\mathrm{A}=\left(\mathrm{a}_{\mathrm{ij}}\right)_{\mathrm{m} \times \mathrm{n}}$

(8) Determine the positive ideal solution $\mathrm{A}+$ and the negative ideal solution $\mathrm{A}^{-}$:

$\mathrm{A}^{+}=\left\{\max _{\mathrm{ij}} \mid \mathrm{i}=1,2, \cdots, \mathrm{m}\right\}=\left\{\mathrm{a}_{1}^{+}, \mathrm{a}_{2}^{+}, \cdots, \mathrm{a}_{\mathrm{n}}^{+}\right\}$

$A^{-}=\left\{\min a_{i j} \mid i=1,2, \cdots, m\right\}=\left\{a_{1}^{-}, a_{2}^{-}, \cdots, a_{n}^{-}\right\}$

(9) Calculate the Euclidean distance from each evaluation unit to the positive and negative ideal solution $\mathrm{l}_{\mathrm{i}}^{+}$and $\mathrm{l}_{\mathrm{i}}^{-}$:

$\mathrm{l}_{\mathrm{i}}^{+}=\sqrt{\sum_{\mathrm{j}=1}^{\mathrm{n}}\left(\mathrm{a}_{\mathrm{ij}}-\mathrm{a}_{\mathrm{j}}^{+}\right)^{2}}(i=1,2, \cdots m)$
$\mathrm{l}_{\mathrm{i}}^{-}=\sqrt{\sum_{\mathrm{j}=1}^{\mathrm{n}}\left(\mathrm{a}_{\mathrm{ij}}-\mathrm{a}_{\mathrm{j}}^{-}\right)^{2}}(i=1,2, \cdots m)$

(10) The grey correlation coefficient between each evaluation unit and the positive and negative ideal solution is calculated $\mathrm{f}_{\mathrm{ij}}^{+}$and $\mathrm{f}_{\mathrm{ij}}^{-}$:

$f_{i j}^{+}=\frac{\min \left|a_{j}^{+}-a_{i j}\right|+\beta \max \left|a_{j}^{+}-a_{i j}\right|}{\left|a_{j}^{+}-a_{i j}\right|+\beta \max \left|a_{j}^{+}-a_{i j}\right|}$ 
$f_{i j}^{-}=\frac{\min \left|a_{j}^{-}-a_{i j}\right|+\beta \max \left|a_{j}^{-}-a_{i j}\right|}{\left|a_{j}^{-}-a_{i j}\right|+\beta \max \left|a_{j}^{-}-a_{i j}\right|}$

(11) The grey relational degree between each evaluation unit and the positive and negative ideal solution is calculated $r_{j}^{+}$and $r_{i}^{-}$:

$r_{i}^{+}=\frac{1}{n} \sum_{j=1}^{n} f_{i j}^{+}, r_{i}^{-}=\frac{1}{n} \sum_{j=1}^{n} f_{i j}^{-}$

(12) The Euclidean distancel ${ }_{i}^{+} 、 l_{i}^{-}$And greyr $_{j}^{+}$、 $\mathrm{r}_{\mathrm{i}}^{-}$Dimensionless treatment:

$$
\begin{aligned}
& \mathrm{R}_{\mathrm{i}}^{+}=\frac{\mathrm{r}_{\mathrm{i}}^{+}}{\operatorname{maxr}_{\mathrm{i}}^{+}}, \mathrm{R}_{\mathrm{i}}^{-}=\frac{\mathrm{r}_{\mathrm{i}}^{-}}{\operatorname{maxr}_{\mathrm{i}}^{-}} \\
& \mathrm{L}_{\mathrm{i}}^{+}=\frac{\mathrm{l}_{\mathrm{i}}^{+}}{\operatorname{maxl}_{\mathrm{i}}^{+}}, \mathrm{L}_{\mathrm{i}}^{-}=\frac{\mathrm{l}_{\mathrm{i}}^{-}}{\operatorname{maxl_{\mathrm {i}}^{-}}}
\end{aligned}
$$

(13) The dimensionless Euclidean distance and the grey relational degree were combined:

$\mathrm{k}_{\mathrm{i}}^{+}=\alpha_{1} \mathrm{R}_{\mathrm{i}}^{+}+\alpha_{2} \mathrm{~L}_{\mathrm{i}}^{-}, \mathrm{k}_{\mathrm{i}}^{-}=\alpha_{1} \mathrm{R}_{\mathrm{i}}^{-}+\alpha_{2} \mathrm{~L}_{\mathrm{i}}^{+}$

$\alpha_{1}+\alpha_{2}=1, \alpha_{1}, \alpha_{2} \in[0,1]$,

Respectively represent the proportion of proximity of position and similarity of shape. $\mathrm{k}_{\mathrm{i}}^{+}$comprehensively reflects the proximity between the evaluation unit and the ideal program, The greater the value, the better the scheme; $\mathrm{k}_{\mathrm{i}}^{-}$comprehensively reflects the proximity between the evaluation unit and the ideal program, and

\begin{tabular}{|c|c|c|c|c|c|}
\hline $\begin{array}{l}\text { The target } \\
\text { layer }\end{array}$ & $\begin{array}{l}\text { Level } \\
\text { indicators }\end{array}$ & $\begin{array}{l}\text { The secondary } \\
\text { indicators }\end{array}$ & Level 3 indicators & $\begin{array}{l}\text { Total } \\
\text { weight }\end{array}$ & $\begin{array}{l}\text { Single } \\
\text { sort } \\
\text { weight }\end{array}$ \\
\hline \multirow{17}{*}{$\begin{array}{l}\text { Level of } \\
\text { green } \\
\text { development } \\
\text { of } \\
\text { agriculture } \\
\text { and animal } \\
\text { husbandry }\end{array}$} & \multirow{7}{*}{$\begin{array}{l}\text { Agricultural } \\
\text { and animal } \\
\text { husbandry } \\
\text { economy }\end{array}$} & \multirow{3}{*}{$\begin{array}{l}\text { Economies of } \\
\text { scale }\end{array}$} & Grain output per capita X1 & 0.0219 & 0.048 \\
\hline & & & Total crop sown area X2 & 0.0756 & 0.1664 \\
\hline & & & Agricultural and animal husbandry practitioners X3 & 0.0916 & 0.2014 \\
\hline & & \multirow{4}{*}{$\begin{array}{l}\text { Economic } \\
\text { efficiency }\end{array}$} & Gross output value of agriculture and animal husbandry X4 & 0.0862 & 0.1895 \\
\hline & & & Agricultural and animal husbandry labor productivity X5 & 0.0793 & 0.1745 \\
\hline & & & Agricultural mechanization degree X6 & 0.0364 & 0.0801 \\
\hline & & & Rate per unit animal husbandry product $\mathrm{X} 7$ & 0.0636 & 0.1410 \\
\hline & \multirow{5}{*}{$\begin{array}{l}\text { Rural social } \\
\text { development }\end{array}$} & \multirow{2}{*}{$\begin{array}{l}\text { The standard } \\
\text { of living }\end{array}$} & The engel's coefficient for rural residents $\mathrm{X} 8$ & 0.0152 & 0.0573 \\
\hline & & & Net income per capita for rural residents X9 & 0.0844 & 0.3181 \\
\hline & & \multirow{3}{*}{ infrastructure } & Rural electricity consumption X10 & 0.0466 & 0.1755 \\
\hline & & & Number of owned medical institutions X11 & 0.0654 & 0.2464 \\
\hline & & & The number of mobile phones per 100 households is $\mathrm{X} 12$ & 0.0538 & 0.2429 \\
\hline & \multirow{5}{*}{$\begin{array}{l}\text { Agricultural } \\
\text { and animal } \\
\text { husbandry } \\
\text { ecological } \\
\text { environment }\end{array}$} & \multirow{3}{*}{$\begin{array}{l}\text { The } \\
\text { environmental } \\
\text { pollution }\end{array}$} & Fertilizer intensity X13 & 0.1142 & 0.4083 \\
\hline & & & agricultural plastic film application intensity X14 & 0.0425 & 0.1519 \\
\hline & & & Intensity of pesticide application X15 & 0.0165 & 0.0589 \\
\hline & & \multirow{2}{*}{$\begin{array}{l}\text { Ecological } \\
\text { management }\end{array}$} & Forest coverage rate $\mathrm{X} 16$ & 0.0610 & 0.2010 \\
\hline & & & Afforestation area $\mathrm{x} 18$ & 0.0504 & 0.1801 \\
\hline
\end{tabular}

Table 2. Weight of evaluation index of green development level of Agriculture and Animal husbandry in Haixi Prefecture

From the level of development of farming and animal husbandry, village green evaluation index weight distribution, the weight index of greater than 0.06 have eight, five of the economic development of the farming and animal husbandry, rural social development has two, one of farming and animal husbandry ecological environment, therefore, in the form of farming and animal husbandry, village green development system of the subsystem, farming and animal husbandry subsystems of economic development is relatively the greater the value, the worse the program.

(14) Relative closeness degree of the calculation scheme:

$\mathrm{Y}_{\mathrm{i}}=\frac{\mathrm{k}_{\mathrm{i}}^{+}}{\mathrm{k}_{\mathrm{i}}^{+}+\mathrm{k}_{\mathrm{i}}^{-}}$

This value represents the relative closeness between the ith evaluation unit and the optimal ideal solution. The greater the closeness, the better the scheme.On the contrary, the smaller the closeness, the worse the scheme.

\subsection{Dynamic evaluation of green development level of Agriculture and Animal husbandry in Haixi Prefecture}

On the basis of constructing the evaluation index of the green development level of Agriculture and animal husbandry in Haixi, the original data of Haixi from 2001 to 2019 were sorted out by consulting the Statistical Yearbook of Qinghai Province and The Statistical Yearbook of Haixi prefecture. The data were standardized, and the index weights were determined by entropy weight method (Table 2). 
After the index weights were calculated, the nearness of each evaluation unit was calculated according to Equations (9) to (20) (Table 3). In order to reflect the dynamic changes in the green development level of agriculture and animal husbandry in Haixi prefecture, figure 1 was made according to the comprehensive evaluation data in Table 3.

Table 3. Green development level of agriculture and Animal husbandry in Haixi Prefecture

\begin{tabular}{|c|c|c|c|c|c|c|c|c|}
\hline \multirow[b]{2}{*}{ year } & \multicolumn{2}{|c|}{ Comprehensive evaluation of } & \multicolumn{2}{|c|}{$\begin{array}{l}\text { Evaluation of economic } \\
\text { development }\end{array}$} & \multicolumn{2}{|l|}{$\begin{array}{l}\text { Social } \\
\text { evaluation }\end{array}$} & $\begin{array}{l}\text { Ecological } \\
\text { assessment }\end{array}$ & environmenta \\
\hline & $\begin{array}{l}\text { Close to } \\
\text { the degree } \\
\text { of }\end{array}$ & $\begin{array}{l}\text { Level of } \\
\text { development }\end{array}$ & $\begin{array}{l}\text { Close to } \\
\text { the degree } \\
\text { of }\end{array}$ & $\begin{array}{l}\text { Level of } \\
\text { development }\end{array}$ & $\begin{array}{l}\text { Close to } \\
\text { the } \\
\text { degree of }\end{array}$ & $\begin{array}{l}\text { Level of } \\
\text { development }\end{array}$ & $\begin{array}{l}\text { Close to } \\
\text { the } \\
\text { degree of }\end{array}$ & $\begin{array}{l}\text { Level of } \\
\text { development }\end{array}$ \\
\hline 2001 & 0.4494 & intermediate & 0.3753 & intermediate & 0.3245 & intermediate & 0.6783 & fine \\
\hline 2002 & 0.4407 & intermediate & 0.3981 & intermediate & 0.3213 & intermediate & 0.6197 & fine \\
\hline 2003 & 0.4275 & intermediate & 0.3709 & intermediate & 0.3542 & intermediate & 0.5800 & intermediate \\
\hline 2004 & 0.4479 & intermediate & 0.3797 & intermediate & 0.3349 & intermediate & 0.6561 & fine \\
\hline 2005 & 0.4612 & intermediate & 0.4121 & intermediate & 0.2935 & poor & 0.6977 & fine \\
\hline 2006 & 0.4392 & intermediate & 0.4482 & intermediate & 0.3454 & intermediate & 0.5206 & intermediate \\
\hline 2007 & 0.4259 & intermediate & 0.4736 & intermediate & 0.3121 & intermediate & 0.4729 & intermediate \\
\hline 2008 & 0.4337 & intermediate & 0.4504 & intermediate & 0.4697 & intermediate & 0.3743 & intermediate \\
\hline 2009 & 0.4888 & intermediate & 0.4248 & intermediate & 0.4693 & intermediate & 0.5980 & intermediate \\
\hline 2010 & 0.4970 & intermediate & 0.4570 & intermediate & 0.5016 & intermediate & 0.5483 & intermediate \\
\hline 2011 & 0.4888 & intermediate & 0.4588 & intermediate & 0.5151 & intermediate & 0.5786 & intermediate \\
\hline 2012 & 0.5247 & intermediate & 0.4526 & intermediate & 0.5205 & intermediate & 0.6298 & fine \\
\hline 2013 & 0.4966 & intermediate & 0.4751 & intermediate & 0.5244 & intermediate & 0.4988 & intermediate \\
\hline 2014 & 0.5168 & intermediate & 0.5348 & intermediate & 0.6348 & fine & 0.3736 & intermediate \\
\hline 2015 & 0.4957 & intermediate & 0.5179 & intermediate & 0.6729 & fine & 0.2873 & poor \\
\hline 2016 & 0.5237 & intermediate & 0.5322 & intermediate & 0.7180 & intermediate & 0.3175 & intermediate \\
\hline 2017 & 0.5361 & intermediate & 0.5284 & intermediate & 0.7513 & fine & 0.3315 & intermediate \\
\hline 2018 & 0.5952 & intermediate & 0.5394 & intermediate & 0.7876 & fine & 0.4809 & intermediate \\
\hline 2019 & 0.5816 & intermediate & 0.5543 & intermediate & 0.7616 & fine & 0.4770 & intermediate \\
\hline
\end{tabular}

Note:Closeness level 0-0.3 is poor,0.3-0.6 is intermediate level0.6-0.8 is good,0.8-1 is high quality.

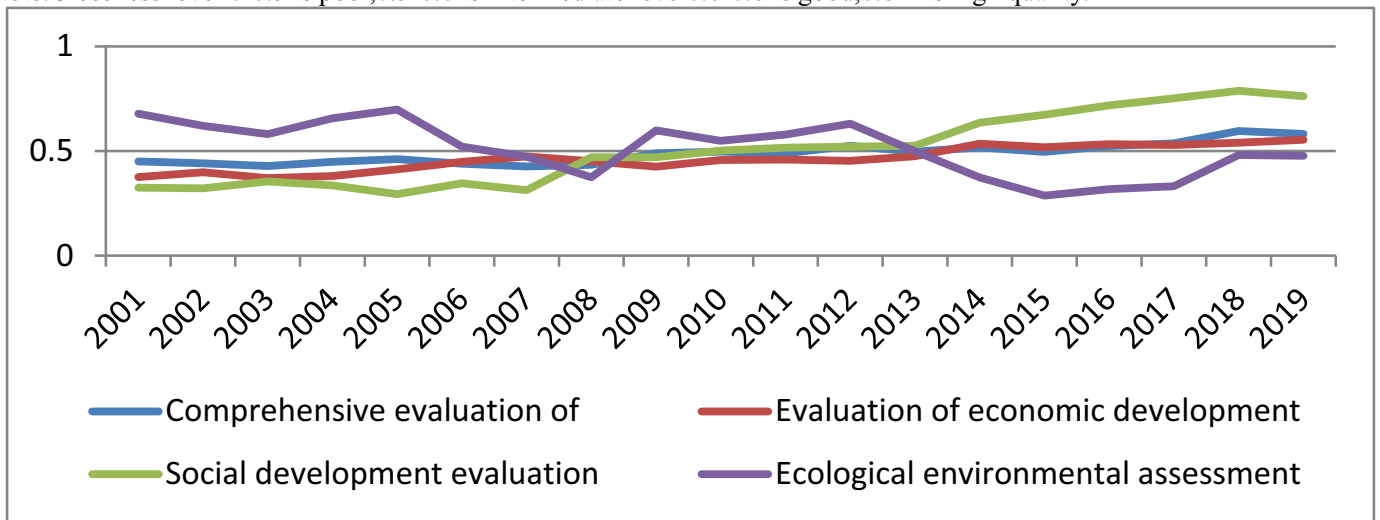

Figure 1. Green development level of Agriculture and Animal husbandry in Haixi prefecture from 2001 to 2019

From Figure 1, it can be clearly seen that the green development level of agriculture and animal husbandry in Haixi was on the rise from 2001 to 2019, and the overall development status was good, and the green development level was constantly improved.The green development index of agriculture and animal husbandry in Haixi autonomous prefecture was 0.4494 in 2001 and 0.5816 in 2019 , indicating that the green development level of agriculture and animal husbandry had been improved, but it still did not break the intermediate level.

The development index of agriculture and animal husbandry economy in Haixi state fluctuates and generally rises.Combined with Table 3 , it can be seen that the development level index of agriculture and animal husbandry economy in Haixi state increased from 0.3753 in 2001 to 0.5543 in 2019 , with an increase of only $0.18 \%$. The rural social development index showed a relatively stable upward trend. Table 3 shows that the rural social development index of Haixi rose from 0.3245 in 2001 to 0.7616 in 2019.The development level of agriculture and animal husbandry ecological environment fluctuates. In Table 3, the development level index of ecological environment decreased from 0.6783 in 2001 to 0.4770 in 2019 . In recent years, with the development of economy, the environment in Haixi city has been polluted to a certain extent.

\section{Conclusions and countermeasures}

By constructing the evaluation index system of the green development level of agriculture and animal husbandry, the entropy weight grey correlation TOPSIS model was used to calculate the green development level of Agriculture and animal husbandry in Haixi autonomous prefecture. The results showed that the green development index of Agriculture and animal husbandry in Haixi autonomous prefecture rose from 0.4494 in 2001 to 0.5816 in 2019 , but still failed to break the intermediate level.The development level of agriculture and animal husbandry economy in Haixi state showed a 
steady rising trend and kept at the intermediate level.The level of social development in rural areas is on the rise, rising from the intermediate level to a good level.The level of agricultural and animal husbandry ecological environment fluctuates, and the level of development in 2015 is poor. In other years, the level of rural social development fluctuates, but remains at the intermediate level.In order to further improve the green development level of agriculture and animal husbandry in Haixi, and promote regional economic and social development and farmers' life improvement, this paper proposes the following countermeasures and suggestions from the three subsystems of green development of agriculture and animal husbandry.

We will improve the structure of the agriculture and animal husbandry industry and promote the healthy development of the agriculture and animal husbandry economy.In order to promote the development of agriculture and animal husbandry economy, we should constantly optimize the industrial structure, deal with the degree of correlation between industries, achieve recycling, avoid waste of resources. While ensuring the supply of agricultural and livestock products, it highlights the non-productive functions of agriculture, such as ecological protection, sightseeing, leisure tourism and cultural inheritance, and attracts capital, talents, technology and other high-quality factors with rich connotations of featured agriculture and animal husbandry, so as to accelerate the transformation and upgrading of the industry.

We will strengthen infrastructure and promote social sustainability. The development of agriculture and animal husbandry economy needs multi-factor input, and farmers and herdsmen need to know more about technology. Therefore, it is necessary to attach importance to the training of farmers and herdsmen's cultural knowledge and skills.It is also necessary to accelerate the construction of transport infrastructure integrating urban and rural areas and strengthen the connectivity between urban and rural areas.We will strengthen the construction of supporting infrastructure such as communications and electric power in farming and pastoral areas.Good infrastructure is the guarantee for efficient organization of production and improvement of people's quality of life. It is also the basis for the green development of agriculture and animal husbandry.

We will promote the development of ecological agriculture and animal husbandry, and improve the ecology and environment of agriculture and animal husbandry.Around the provincial party committee proposed "from farmers and herdsmen single planting, breeding, ecological care to ecological virtuous circle of production and life of" new concept, accelerating the development of farming and animal husbandry, on the basis of carrying out ecological comprehensive treatment engineering, and actively build green ecological, zero growth action actively developing chemical fertilizers and agricultural pollution source management, promote green production mode [6]. The cultivation of farmers and herdsmen's awareness of environmental protection and ecology can achieve the new goals of tidiness of the countryside, recycling of manure, reduction of fertilizer and medicine, improvement of product quality, reduction of resource dependence, and beauty of ecological environment, so as to realize the virtuous cycle of ecology and life.

\section{References}

1.Zhao, K.(2018) Research on the Development of modern Agriculture and Animal husbandry in western Semi-agricultural and semi-pastoral Areas under the Green Development View.

2.Ye,L,N.(2018) Study on the Level measurement and influencing factors of Agricultural green development in Ningxia.

3.Wang,J,J.(2016) Study on performance Evaluation and Influencing Factors of Green Development in Chinese Rural areas.

4.Zhang,H.(2016)The measurement of green development level and its spatial relationship in Hubei Province.

5.Zheng,H,N.(2013) Construction and Evaluation of China's Green Development System Model.

6.Yang,Y,Z.(2018) Analysis on the development of agriculture and Animal husbandry in Haixi Prefecture. 